\title{
Contrasting molecular and morphological evidence for the identification of an anomalous Buteo: a cautionary tale for hybrid diagnosis
}

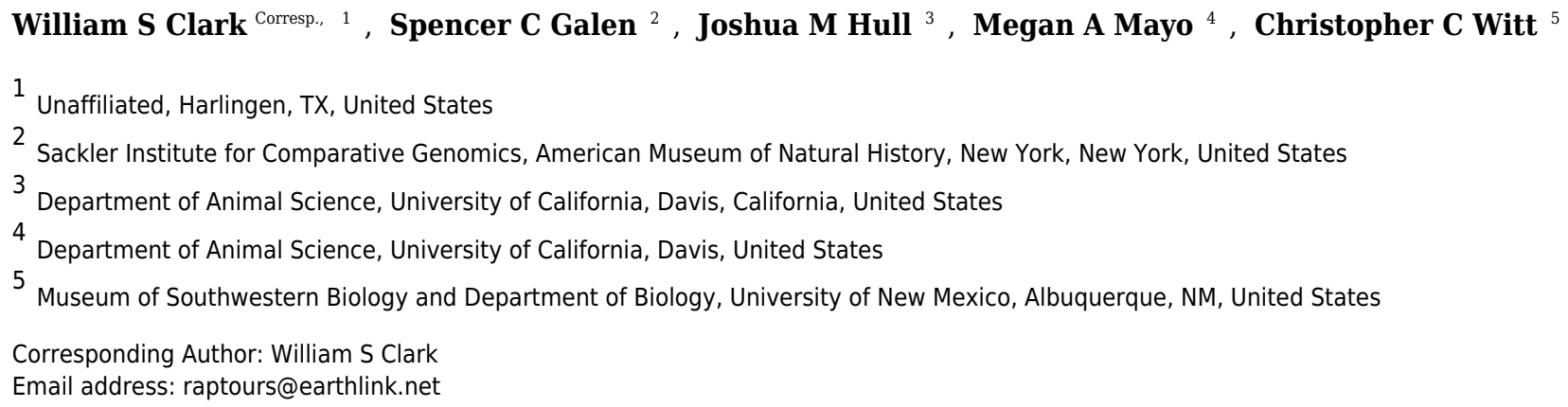

An adult Buteo was found dead as a road-kill south of Sacramento, California, and was thought to represent the first state record of the eastern Red-shouldered Hawk ( $B$. lineatus lineatus; Pyle et al. 2004). It is now a specimen in the Museum of Wildlife and Fisheries Biology (WFB 4816) at the U. of California, Davis. We examined this specimen and found that many of its plumage characters differed from all other adult Red-shouldered Hawks examined, including nominate adults. Plumage markings and measurements were intermediate between Red-tailed Hawk (Buteo jamaicensis, ssp calurus) and Redshouldered Hawk (ssp elegans), leading us to hypothesize that the bird was a hybrid. However, mtDNA sequences and nuDNA microsatellites proved definitively that the bird was a Red-shouldered Hawk, most likely of eastern origin. This case illustrates that apparent hybrids or apparent vagrants could be individuals with anomalous phenotypes caused by rare genetic variation or novel epigenetic effects. 
1 Contrasting molecular and morphological evidence for the identification of an anomalous Buteo:

2 a cautionary tale for hybrid diagnosis

3 William S. Clark, (raptours@,earthlink.net), 2301 South Whitehouse Circle, Harlingen, TX

5 Spencer C. Galen, Sackler Institute for Comparative Genomics, American Museum of Natural

8 Joshua M. Hull, Department of Animal Science, University of California, Davis, California, 95616

10 Megan A. Mayo, Department of Animal Science, University of California, Davis, California,

12 Andrew Engilis, Jr., Museum of Wildlife and Fish Biology, University of California, Davis, California, 95616

Christopher C. Witt, Department of Biology and Museum of Southwestern Biology, University of New Mexico, Albuquerque, New Mexico, 87131, USA 


\section{ABSTRACT.}

18 Character states that are intermediate between two species generally comprise evidence of hybrid parentage. Here we examined an adult Buteo that was found dead as a road-kill south of

20 Sacramento, California, and was thought to represent the first state record of the eastern Red-

21 shouldered Hawk (B. lineatus lineatus; Pyle et al. 2004). It is now a specimen in the Museum of

22 Wildlife and Fish Biology (WFB 4816) at the U. of California, Davis. We examined this

23 specimen and found that many of its plumage characters differed from all other adult Red-

24 shouldered Hawks examined, including eastern adults. Plumage markings and measurements

25 were somewhat similar to Red-shouldered Hawk (B. lineatus ssp.) but with characters suggesting

26 Red-tailed Hawk (B. jamaicensis), leading us to hypothesize that the bird might be a hybrid,

27 possibly of local origin. However, mtDNA sequences and nuDNA microsatellites provided a

28 match with the eastern subspecies of Red-shouldered Hawk and no evidence of hybridization.

29 The conflicting phenotypic and genotypic evidence regarding the identity of this vagrant

30 specimen may have been caused by a second-generation (or higher) backcross after

31 hybridization, a rare allele of large effect, or an epigenetic developmental abnormality. This case

32 illustrates that the diagnosis of apparent hybrids should be conducted with caution and

33 consideration of alternative explanations. 


\section{INTRODUCTION}

Hybridization often occurs between sympatric populations of closely related species, and it is a process that can have important evolutionary consequences (Seehausen, 2004; Rheindt and Edwards 2011). Hybridization can accelerate or slow speciation (Abbott et al., 2013), can rescue inbred lineages (Frankham, 2015), and can lead to extinction (Allendorf et al., 2001). Often the youngest, or most recently radiated species experience hybridization (Mallet, 2005). Raptors of the genus Buteo are part of a rapid, recent radiation in which many species overlap in their distribution (Riesing et al. 2003). Several cases of hybridization among Buteo species have come to light relatively recently (e.g., Dudás et al. 1999, Pfander and Schmigalew 2001, Clark and Witt 2006, Hull et al. 2007a, Corso and Gildi 2007, Gjershaug 2010), often resulting in individuals with intermediate characteristics.

In this study, we examined an adult specimen that was similar in physical characteristics to adult Red-shouldered Hawks (B. lineatus), but with certain traits that were intermediate between Red-shouldered Hawk and Red-tailed Hawk (B. jamaicensis). This hybrid combination has not been previously noted in the peer-reviewed literature. This specimen provided an opportunity to use morphological and genetic data to more closely examine the possibility of hybridization between two species that are mobile and wide-ranging in North America. The specimen, found dead south of Sacramento, California, on 21 September 1996, had been described previously as a vagrant eastern Red-shouldered Hawk (B. l. lineatus), the first record for that taxon in California (Pyle et al. 2004). However, the possibility of hybrid status was not examined quantitatively, and no molecular data were used. We re-evaluated the findings of Pyle et al. (2004) for three reasons: (1) Many of the plumage markings and morphological measurements appeared to be different from Red-shouldered Hawk; (2) several recent records of hybrids between Buteo species suggest 
58 that hybridization is plausible; and (3) understanding circumstances where hybridization occurs

59 can illuminate ongoing evolutionary processes within this genus.

60

\section{METHODS}

62 We examined the plumage patterns and colors of 76 specimens of adult eastern and western

63 Red-shouldered Hawks in nine museums (Appendix 1). We scored the following characters:

64 malar and throat color, color and markings of the remiges and upper tail coverts, color of the

65 lesser upper wing coverts, and the number of white tail bands. We compared these characters to

66 those of the putative hybrid (WFB 4816). In an effort to find any eastern Red-shouldered Hawk

67 individual that exhibited the plumage characters of WFB 4816, we examined more than 200

68 images of adult Red-shouldered Hawks in field guides and by using Google Image Search, and

69 we examined photographs of 48 eastern adults captured for banding. After failing to find any

70 Red-shouldered Hawks that resembled WFB 4816, we examined the 54 adult female specimens

71 of eastern Red-shouldered Hawks in the U. S. National Museum (USNM) that served as

72 reference for Pyle et al. (2004).

73 We measured the wing chord, exposed culmen length, hallux chord, tarsus length, and standard

74 tail length of adult specimens of three taxa: western Red-tailed Hawks (B. j. calurus) from

75 California ( $n=23)$, Red-shouldered Hawks from California (B. l. elegans; $N=33$ ), and eastern

76 North America (B. l. lineatus; $\mathrm{N}=46$ ), respectively. We centered and scaled the variables prior to

77 conducting a principle components analysis (PCA) using the command prcomp in the stats

78 package in R (http://www.r-project.org/). Individual measurements are shown in Appendix 1.

79 After determining that the hallux chord measurement of WFB 4816 was larger than that of any

80 Red-shouldered Hawk, we measured the halluces of additional specimens of adult females of $B$. 
81 l. lineatus from the Burke Museum (UWBM), Field Museum (FMNH), Museum of Vertebrate

82 Zoology (MVZ), the Smithsonian Institution (USNM), and the Western Foundation of

83 Vertebrate Zoology (WFVZ). This gave us measurements from a total of 98 adult female

84 specimens of the nominate subspecies.

85 We extracted DNA from a toepad sample of WFB 4816 using a modified Qiagen DNeasy kit

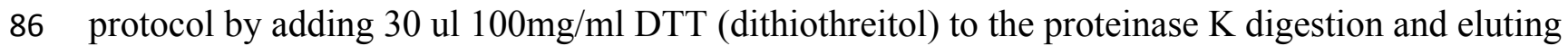

87 the sample in $50 \mu \mathrm{l}$ instead of the standard $200 \mu \mathrm{l}$. A negative control was included during the

88

extraction process. We designed primers that amplify a $191 \mathrm{bp}$ fragment of the mitochondrial gene ND2 (buteoND2F: CTGAACAAAATCCCCCACAC; buteoND2R:

CGAGGCGGAGGTAGAAGAAT), and PCR amplified this fragment using 45 cycles of $94^{\circ}$ for $30 \mathrm{~s}, 50^{\circ}$ annealing for $30 \mathrm{~s}$, and $72^{\circ}$ extension for 1 minute. We Sanger-sequenced this PCR product on an ABI 3130 machine.

Extracted DNA was amplified and genotyped for 18 microsatellite loci (A110, A302, A303, B111a, B220, B221, D107, D122, D123, D127, D207, D220, D223, D234, D235, D310, D327, D330) in six multiplex PCRs following the conditions described in Hull et al. (2007b). PCR products were separated with a 3730 DNA Analyzer (Applied Biosystems Inc.), and then scored using STRAND version 2.3.89 (Toonen and Hughes 2001). For comparison, we obtained genotypes from these loci for eastern and western Red-shouldered Hawks and Red-tailed Hawks from previous population genetic studies of these species (Hull et al. 2008a, Hull et al. 2008b).

To visualize the genetic relationships of the possible hybrid specimen with putative parental taxa, we performed a factorial correspondence analysis (FCA) (GENETIX 4.05.2; Belkhir et al. 2000). The FCA clustered genotypic groups based on microsatellite allele frequencies using the ordination of samples along varying factorial axes to visualize genetic similarity of the samples 
104 in two-dimensional space. In this analysis, a hybrid individual would be indicated by its

105 intermediate location in the FCA between the genotypic groups for Red-shouldered and Red-

106 tailed Hawks.

107 We also investigated the ancestry of the museum specimen through assignment tests using a 108 Bayesian clustering algorithm (STRUCTURE version 2.1; Pritchard et al. 2000). This analysis

109 was first performed comparing the museum specimen with a combined eastern and western 110 sample of Red-shouldered Hawks and a sample of Red-tailed Hawks. Subsequently, we

111 performed a second analysis comparing the museum specimen to separate eastern Red-

112 shouldered hawks and western Red-shouldered Hawks. No Red-tailed Hawks were included in

113 the second test. For both analyses we used the population admixture model with a population

114 prior corresponding to either species (test 1) or sampling location (test 2) and assumed that allele

115 frequencies were correlated among populations. We ran the simulation with a 10,000 iteration

116 burn-in and a run length of 100,000 iterations. We limited the analysis to $\mathrm{K}=2$ (where $\mathrm{K}$ is the

117 number of populations) because of our prior knowledge of the species and geographic origin of

118 the samples. We then generated Q plots to visualize proportion of ancestry for the museum

119 specimen in relationship to possible populations of origin.

\section{RESULTS}

122 The putative hybrid specimen (WFB 4816) differed in eight plumage characters from all adult

123 Red-shouldered Hawks that we examined (130 specimens and >250 photographs for plumage

124 and 79 specimens for measurements). Plumage differences are summarized in Table 1. Figure

125 1A shows that the putative hybrid has a dark throat, whereas typical adult Red-shouldered

126 Hawks have pale throats with dark malar stripes. The putative hybrid also shows dark brown

127 barring on the belly, a feature not exhibited by any adult Red-shouldered Hawk. Figure 1B 
128 shows that the putative hybrid has seven narrower white tail bands; in contrast, adult Red-

129 shouldered Hawks usually have three or four wider bands (but a few had five bands). The tail

130 bands and upper tail coverts on the putative hybrid show rufous tinges that are not seen on any

131 adult Red-shouldered Hawk. Figure 1C shows the lack of white spotting on the uppersides of the

132 remiges of the putative hybrid, whereas adult Red-shouldered Hawks always show numerous

133 white spots. The lack of rufous on the lesser upper wing coverts of the putative hybrid is another

134 characteristic that is inconsistent with Red-shouldered Hawk (shoulder; Fig. 1c). Many of the

135 plumage differences listed above were also visible in Fig. 1 of Pyle et al (2004).

136 Although the 54 adult female specimens of eastern Red-shouldered Hawks in the USNM

137 collection had been consulted for the original identification of WFB 4816 as an eastern Red-

138 shouldered Hawk, we found that none of these shared the combination of plumage traits

139 exhibited WFB 4816. Seventeen of these USNM specimens showed five white tail bands, but

140 none had seven as shown by WFB 4816. One had a mostly dark throat that was the same color as

141 the malars, but it also had white streaks in the dark throat. Another specimen had gray markings

142 on the upper wing coverts, but its remige tips and tail bands were white.

143 The largest hallux measurement on any adult female eastern Red-shouldered Hawk we

144 measured was $23.9 \mathrm{~mm}$ (range 19.2-23.9 mm, $\bar{x}=22.1, \mathrm{SD}=1.0, \mathrm{n}=98$; Appendix 2); all were

145 smaller than that of the putative hybrid specimen, $25.1 \mathrm{~mm}$, which was more than two standard

146 deviations greater than the mean of these measurements.

147 The PCA analysis of morphological measurements showed that eastern and western Red-

148 shouldered Hawks each formed distinct clusters, but with some overlap. Red-tailed Hawks

149 formed a separate, discrete cluster. The putative hybrid specimen fell outside of the ranges of

150 measurement of any of the three taxa in our PCA (Figure 2). Although it was closest to eastern 
151 Red-shouldered Hawks, it was also outside of the range of variation observed in other eastern

152 Red-shouldered Hawks, and it was in between the centroids of California Red-shouldered Hawks

153 and California Red-tailed Hawks on the PC1 axis, which explained $80.5 \%$ of the variance.

154 We successfully sequenced the complete 191 bp ND2 fragment of the specimen, WFB 4816

155 (GenBank accession number: KX154215). An NCBI BLAST search revealed that the sequence

156 has 100\% sequence identity to Red-shouldered Hawk (EU583276.1) and 99\% similarity to two

157 additional Red-shouldered Hawk sequences (GQ264875.1, GQ264874.1). All Red-tailed Hawk

158 ND2 sequences on GenBank differ from WFB 4816 by at least 7 substitutions in the sequenced

159 fragment (96\% similarity).

160 Mitochondrial DNA (mtDNA) showed that the putative hybrid matches Red-shouldered Hawk, 161 providing decisive evidence that its mother was a Red-shouldered Hawk. However, the mtDNA 162 haplotype that we recovered was shared between eastern and western North American

163 populations of Red-shouldered Hawk, so no geographic assignment could be made on the basis 164 of mtDNA.

165 We recovered data from WFB 4816 for nine of the 18 microsatellite loci. Our failure to obtain 166 data for the other nine loci was likely as a result of degraded DNA. The factorial correspondence 167 analysis of the microsatellite data showed distinct clusters of individuals corresponding to Red168 tailed Hawks and Red-shouldered Hawks in the comparison between these species (Fig. 3A), 169 with WFB 4816 grouping within the Red-shouldered Hawk cluster. (Appendix 3 is the raw 170 microsat data.) In the second factorial correspondence analysis, we found two clusters 171 corresponding to eastern and western Red-shouldered Hawks with an area of overlap between 172 the two (Fig. 3B). In this second analysis WFB 4816 grouped within the eastern Red-shouldered 173 Hawk cluster. 
174 The Bayesian clustering analysis revealed a similar pattern to that seen in the factorial

175 correspondence analysis. In the first analysis when $\mathrm{K}$ was set to 2 we found two distinct groups

176 with very high proportions of ancestry corresponding to either Red-tailed Hawks or Red-

177 shouldered Hawks (Fig. 4A). In this analysis, WFB 4816 showed ancestry solely from Red-

178 shouldered Hawks. In the second analysis, the two a priori partitions $(K=2)$ corresponded to

179 groupings of eastern and western Red-shouldered Hawks with low levels of admixture between 180 the two groups (Fig. 4B). In this case, WFB 4816 showed a high proportion of ancestry derived 181 from eastern Red-shouldered Hawks.

\section{DISCUSSION}

184 The microsatellite data for WFB 4816 provided a match with eastern group of Red-shouldered 185 Hawks, corroborating the original conclusion of Pyle et al. (2004) that the specimen was a vagrant to California. Records of eastern Red-shouldered Hawks outside of their eastern range, 187 though rare, have been recorded previously, including a juvenile specimen that was salvaged in Albuquerque, New Mexico, in 1991 (MSB:Bird:8174). The fact that nine microsatellite loci contained no evidence of mixed ancestry rules out the possibility that the specimen represents an hybrid between eastern Red-shouldered Hawk and Red-tailed Hawk (F1) because such a hybrid would have nine microsatellite alleles of Red-tailed Hawk origin. A first generation backcross (BC1) with eastern Red-shouldered Hawk would be expected to retain four-and-a-half Red-tailed Hawk alleles, on average, so would most likely have been detectable by our data. At the second backcross generation (BC2), an average of two-and-a-quarter Red-tailed Hawk alleles would be expected in our data, but the stochastic nature of Mendelian segregation makes it reasonably probable that our microsatellite data would fail to detect Red-tailed Hawk ancestry, even while 
197 one-eighth of the genome would be of Red-tailed Hawk origin. At subsequent backcross

198 generations with eastern Red-shouldered Hawk, the genetic contribution of Red-tailed Hawk

199 would certainly be too dilute to detect with a data set of this size (Lavretsky et al. 2015).

200 In contrast to our microsatellite data, the results of our analyses of phenotype were inconsistent

201 with the conclusion of Pyle et al. (2004) that the specimen represented a eastern Red-shouldered

202 Hawk. The morphometric measurements and plumage traits of WFB 4816 were atypical for Red-

203 shouldered Hawk and appeared to be at least somewhat intermediate between Red-tailed Hawk

204 and Red-shouldered Hawk, suggesting that the specimen represented a hybrid or a subsequent

205 backcross with Red-shouldered Hawk. The first principle component of the morphological

206 measurements (PC1), which provides an index of overall size (Wright et al. 2016), showed that

207 this specimen was larger than any of the 46 eastern Red-shouldered Hawk specimens for which

208 we measured all five traits. Furthermore, its combination of plumage markings did not occur in

209 any specimen or photograph that we examined and resembled an amalgamation of characteristics

210 from both species.

211 How can we reconcile the apparent conflict between our genetic and phenotypic results? Hybrid

212 individuals (F1) are typically intermediate in size and plumage between the parental species

213 (Rohwer 1994), but our microsatellite results preclude the possibility that WFB 4816 represents

214 an F1 and they cast doubt on the possibility of a BC1 backcross with eastern Red-shouldered

215 Hawk. However, our microsatellite results clearly cannot rule out a backcross at generation BC2

216 or higher. Thus, we cannot rule out the possibility that a Red-tailed Hawk contribution of one-

217 eighth or less of the genome may have caused the unusual phenotype of WFB 4816, after two or

218 more generations of backcrossing with eastern Red-shouldered Hawks. It is important to note

219 that at each backcross generation, offspring are expected to increasingly resemble the 
220 backcrossed parental species due to exponential dilution of hybrid-origin alleles that underlie the

221 phenotype. Consistent with the expectation under hybridization and subsequent backcrossing, the

222 phenotype of WFB 4816 appears to be more similar overall to Red-shouldered Hawk than to

223 Red-tailed Hawk (Fig. 1, Fig. 2, Table 1). Thus, hybridization followed by two generations of

224 backcrossing is a viable explanation for WFB 4816, but additional genetic data would be

225 required to test this hypothesis.

226 Occasional hybridization may result in reciprocal exchange of alleles between species if

227 resultant offspring can successfully backcross, and particularly if an allele confers a selective

228 advantage to the recipient species (Rheindt and Edwards 2011). The plausibility of Red-tailed

229 Hawk origin for the atypical characteristics of WFB 4816, whether by adaptive introgression or

230 hybridization followed by two or more generations of backcrossing, is supported by a growing

231 set of documented examples of hybridization involving species in the genus Buteo. A putative

232 juvenile hybrid specimen in the collection of the Cleveland Museum of Natural History (catalog

233 no. 69422) was banded in the nest near Cleveland, Ohio, and later found dead in the nearby area.

234 Mother was a Red-tailed Hawk, and father was a Red-shouldered Hawk. Measurements and

235 plumage traits are inconsistent with juveniles of either species. Photographs of an adult hybrid

236 between Red-tailed Hawks and Red-shouldered Hawk from Connecticut have been posted on-

237 line (Connecticut Audubon Society blog, January 6, 2011). Additional Buteo hybrids include

238 those reported by Clark and Witt (2006), a hybrid specimen of Rough-legged (B. lagopus) x

239 Swainson's (B. swainsoni) Hawks, and Hull et al. (2007) on several cases of hybrids between

240 Red-tailed and Swainson's Hawks. Both of these papers also used DNA, plumages, and

241 morphometrics to determine hybridization. We have examined unpublished photographs of two

242 adults that show characters of two species, one of Red-tailed and Ferruginous (B. regalis) Hawks 
243 and the other of Red-tailed and Rough-legged Hawks. Four further hybridizations between two

244 species of Buteo have been reported from Eurasia-Rough-legged x Common (B. buteo)

245 Buzzards (Gjershaug et al. 2010), Long-legged x Common Buzzards (Dudás et al. 1999, Corso

246 2007), and Long-legged x Upland (B. hemilasius) Buzzards (Pfander and Schmigalew. 2001).

247 Clark et al. (2005) reported on four instances of hybrids, three between species in Buteo, but also

248 an intergeneric case of Swainson's Hawk male and Red-backed Buzzard (Geranoaetus

249 polyosoma) in Colorado (Allen 1998). The most phylogenetically distant hybrid pairing

250 involving a Buteo is that reported by Corso and Gildi (1998) from Italy of a Common Buzzard

251 mated with a Black Kite (Milvus migrans) that produced two fledglings.

252 There are at least two alternative explanations for the anomalous phenotype of WFB 4816 that

253 would not involve a genetic contribution from Red-tailed Hawk. First, the bird may have been

254 subject to epigenetic, developmental abnormalities such as those that can be caused by

255 environmental factors (Wong et al. 2005). Second, an allele of large effect (Thompson and

256 Jiggins 2014) may have arisen via mutation or may be segregating in the population at such low

257 frequency that it was previously undetected.

258 On the basis of our results, we conclude that WFB 4816 is an eastern Red-shouldered Hawk

259 that is both a vagrant to California and an individual with an anomalous phenotype of uncertain

260 cause. The confluence of these two unlikely events suggests that they are linked, and it is

261 plausible that a rare allele of large effect, hybridization with Red-tailed Hawk two or more

262 generations earlier, or an epigenetic developmental abnormality could have jointly affected the

263 phenotype and the direction of migratory orientation. The compass direction of migratory

264 orientation is generally subject to genetic control (Helbig 1996). 
Hybrid diagnoses that fail to obtain definitive genetic evidence of hybridization should consider at least three alternative explanations for phenotypic character states that are apparently intermediate between two parental species: (1) rare alleles of large effect that originated via mutation; (2) alleles of hybrid origin that persisted or introgressed after backcrossing, or (3) epigenetic developmental abnormalities. As whole-genome sequencing from museum specimens becomes increasing feasible (McCormack et al. 2015), we will be better able to empirically distinguish among these potential causes of unusual and anomalous phenotypes.

\section{ACKNOWLEDGEMENTS}

We would like to thank the American Museum of Natural History, the Museum of Southwestern Biology of the University of New Mexico, the U. S. National Museum, the Western Foundation of Vertebrate Zoology, and the Museum of Wildlife and Fish Biology of the University of California-Davis for making their collections open to our study.

\section{LITERATURE CITED}

ABBOTT, R., ALBACH, D., ANSELL, S., ARNTZEN, J.W., BAIRD, S.J.E., BIERNE, N., BOUGHMAN, J., BRELSFORD, A., BUERKLE, C.A., BUGGS, R. and BUTLIN, R.K., 2013. Hybridization and speciation. Journal of Evolutionary Biology 26:229-246.

ALLEN, S. 1988. Some thoughts on the identification of Gunnison's Red-backed Hawk (Buteo polyosoma) and why it's not a natural vagrant. Journal of the Colorado Field Ornithologists 22:9-14. 
286 287 288

ALLENDORF, F. W., LEARY, R. F., SPRUELL, P., and WENBURG, J. K. 2001. The problems with hybrids: setting conservation guidelines. Trends in Ecology and Evolution 16: 613-622.

BELKHIR, K., BORSA, P., CHIKHI, L., RAUFASTE, N., and BONHOMME, F. 1996-2001. GENETIX 4.02, logiciel sous Windows TM pour la génétique des populations, Laboratoire Génome, Populations, Interactions; CNRS UMR 5000; Université Montpellier II, Montpellier, France.

.CLARK, W. S., M. REID, and B. K. WHEELER. 2005. Four cases of hybridization in North American Buteos. Birding 37:256-263.

CLARK, W. S., and C. C. WITT. 2006. First known specimen of a hybrid Buteo: Swainson's Hawk (Buteo swainsoni) x Rough-legged Hawk (B. lagopus) from Louisiana. Wilson Journal of Ornithology 118:42-52.

CORSO, A. and GILDI, R. 1998. Hybrids between Black Kite and Common Buzzard in Italy in 1996. Dutch Birding 20: 226-233

DUDÁS, M., J. TAR, and I. TÓTH. 1999. [Natural hybridization of Long-legged Buzzard (Buteo rufinus) and Common Buzzard (B. buteo) in the Hortobagy National Park.] In Hungarian. Ölyvek,, keveredése”. Temészet, 5-6:8-10.

FRANKHAM, R. 2015. Genetic rescue of small inbred populations: a meta-analysis reveals large and consistent benefits of gene flow. Molecular Ecology 24: 2610-2618.

GJERSHAUG, J. O., O. A. FORSET, K. WOLDVIK and Y. ESPMARK. 2010. Hybridisation between Common Buzzard Buteo buteo and Rough-legged Buzzard B. lagopus in Norway. Bull. B.O.C. 2006 126(1):73-80. 
HELBIG, A. J. 1996. Genetic bases, mode of inheritance and evolutionary changes in migratory directions in Palaearctic warblers. J. Experimental Biol. 199:45-54.

HULL, J. M., W. SAVAGE, J. P. SMITH, N. MURPHY, L. CULLEN, A. C. HUTCHINS, and H. B. ERNEST. 2007. Hybridization among Buteos: Swainson's Hawks (Buteo swainsoni) X Red-tailed Hawks (Buteo Jamaicensis). The Wilson Journal of Ornithology 119(4):579-584.

HULL, J. M., A. C. HULL, B. N. SACKS, J. P. SMITH, and H. B. ERNEST. 2008a Landscape characteristics influence morphological and genetic differentiation in a widespread raptor (Buteo jamaicensis). Molecular Ecology 17:810-824.

HULL, J. M., B. N. STROBEL, C. W. BOAL, A. C. HULL, C. R. DYKSTRA, A. M. IRISH, A. M. FISH, and H. B. ERNEST. 2008b. Comparative phylogeography and population genetics within Buteo lineatus reveals evidence of distinct evolutionary lineages. Molecular Phylogenetics and Evolution 49: 988-996.

MALLET, J. 2005. Hybridization as an invasion of the genome. Trends in Ecology and Evolution 20: 229-237.

MCCORMACK, J. E., W. L. E. TSAI, and B. C. FAIRCLOTH. 2015. Sequence capture of ultraconserved elements from bird museum specimens. Molecular Ecology Resources. doi: 10.1111/1755-0998.12466

PFANDER, P. and S. SCHMIGALEW. 2001. [Extensive hybridization of Long-legged Buzzard Buteo rufinus and Upland Buzzard B. hemilasius.] In German. Ornithologische Mitteilung 53:344-349.

PRITCHARD J,. K, STEPHENS, and M, DONNELLY. 2000. Inference of population structure using multilocus genotype data. Genetics, 155, 945-959. 
331 PYLE, P., A. ENGILIS, JR., and T. G. MOORE. 2004. A specimen of the nominate subspecies

332 of the Red-shouldered Hawk from California. Western Birds 35:100-104.

333 RHEINDT, F. E., and S. V. EDWARDS. 2011. Genetic introgression: an integral but neglected 334 component of speciation in birds. Auk 128:620-632.

335

RIESING, J. M., L. KRUCKENHAUSER, A. GAMAUF, AND E. HARING. 2003. Molecular phylogeny of the genus Buteo (Aves: Accipitridae) based on mitochondrial marker sequences, Molecular Phylogenetics and Evolution 27(2):328-342.

ROHWER, S. 1994. Two new hybrid Dendroica warblers and new methodology for inferring parental species. Auk 111:441-449.

SEEHAUSEN, O. 2004. Hybridization and adaptive radiation. Trends in Ecology and Evolution 19: $198-207$.

THOMPSON, M. J. and C. D. JIGGINS. 2014. Supergenes and their role in evolution. Heredity $113: 1-8$.

TOONEN RJ, and S. HUGHS. 2006. Increased throughput for fragment analysis on an ABI PRISM (R) 377 automated sequencer using a membrane comb and STRAN software. BioTechniques, 31, 1320-1439.

WONG, A. H. C., I. I. GOTTESMAN, and A. PETRONIS. 2005. Phenotypic differences in genetically identical organisms: the epigenetic perspective. Hum. Mol. Genet. 14 (suppl 1): R11-R18, doi:10.1093/hmg/ddi116

WRIGHT, N. A., D. STEADMAN, and C. C. WITT. 2016. Predictable evolution toward flightlessness in volant island birds. Proceedings of the National Academy of Sciences, USA, 113:4765-4770. 

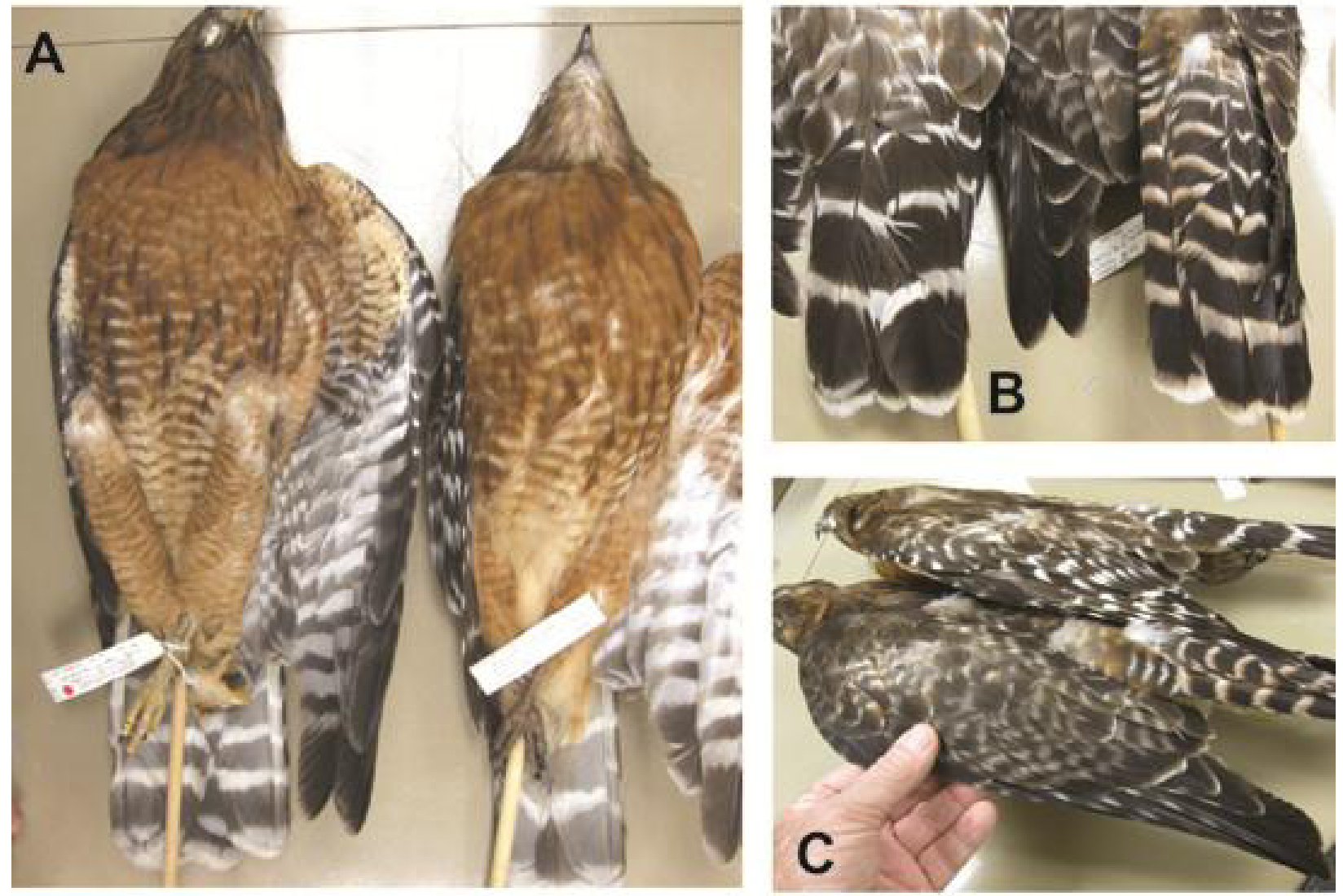

355 Figure 1. Comparison of adult Eastern Red-shouldered Hawk (r) with WFB 4816 (l). A. 356 Undersides. Note dark throat and dark belly markings of WFB 4816. B. Upper tails. Note six 357 tail bands of WFB 4816. C. Upper wings. Note lack of white spotting on upper wings of WFB 3584816. 


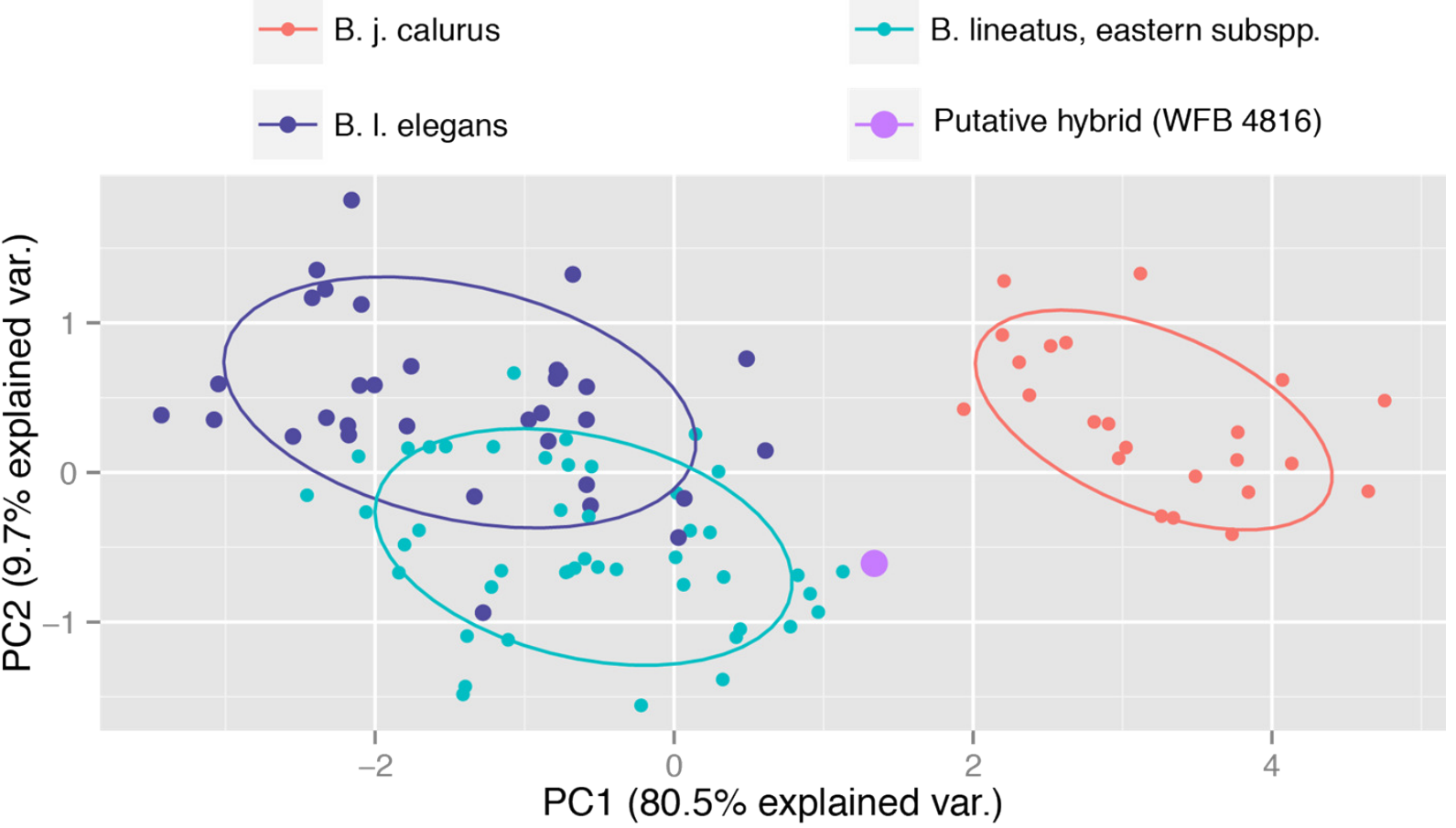

366 Figure 2. Plot of the first two principle components based on the PCA of five measurements 367 from 103 adult eastern Red-shouldered Hawks (B. lineatus subspp.), California Red-shouldered 368 Hawks (B. l. elegans), and western Red-tailed Hawks (B. j. calurus) representing both sexes 369 showing that the putative hybrid is intermediate in its morphometric measurements between Red370 shouldered Hawk and Red-tailed Hawk. 

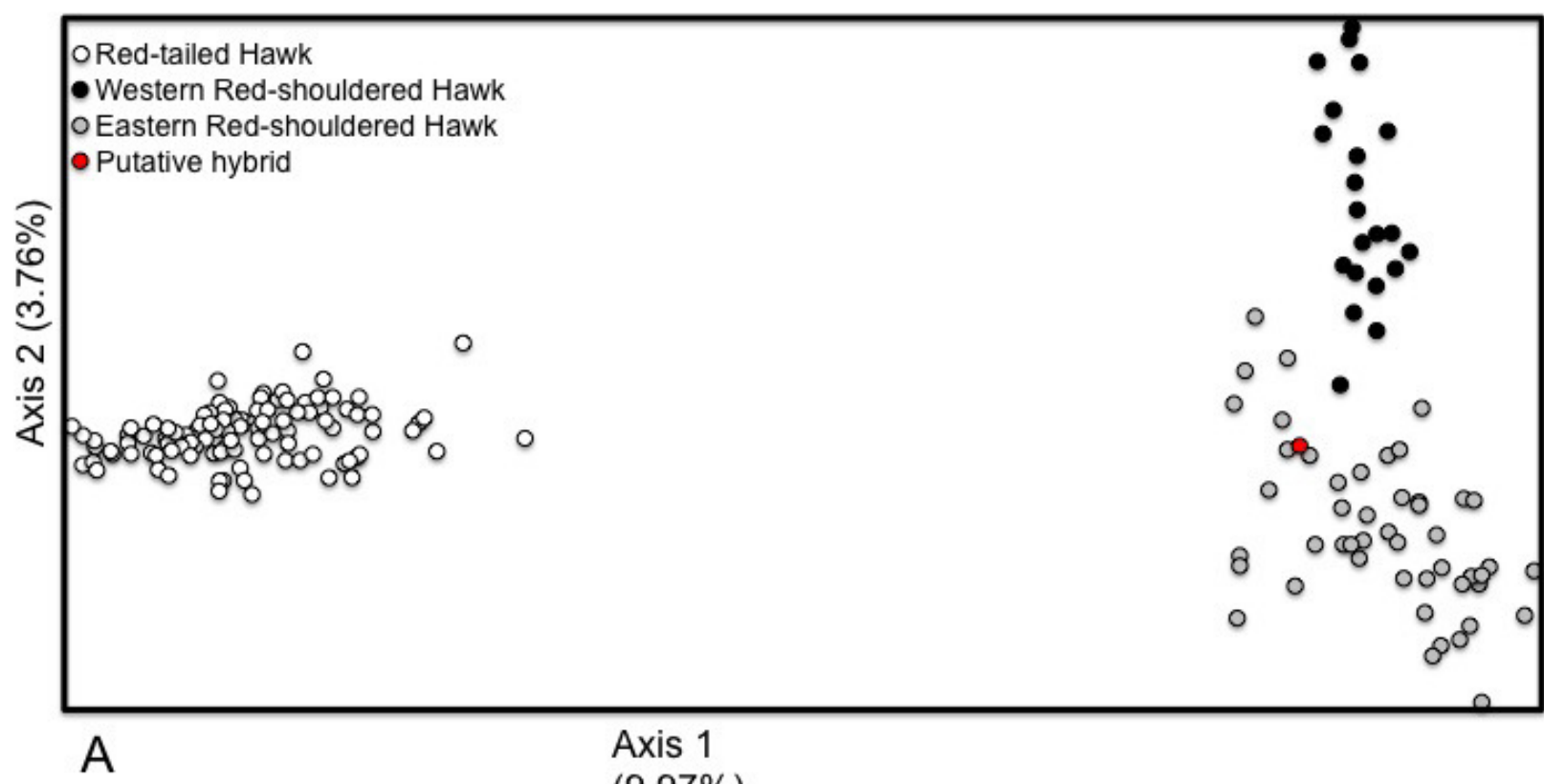

$(9.97 \%)$

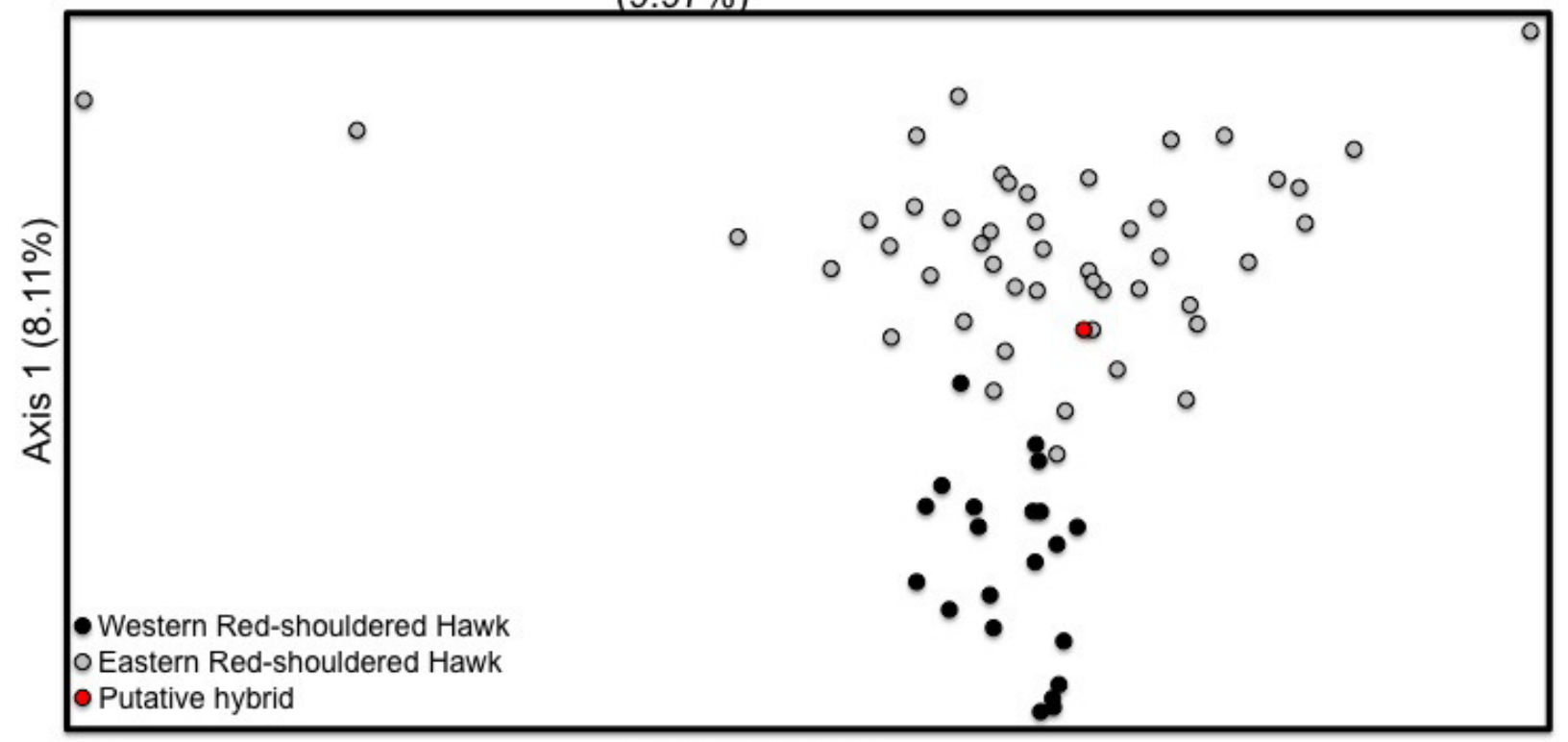

B

Axis $2(6.04 \%)$

373 Figure 3. Results of the factorial correspondence analysis (FCA) of microsatellite loci for WFB

3744816 (yellow circles) compared to (A) eastern and western Red-shouldered Hawks, and (B)

375 eastern and western Red-shouldered Hawks and western Red-tailed Hawks. 

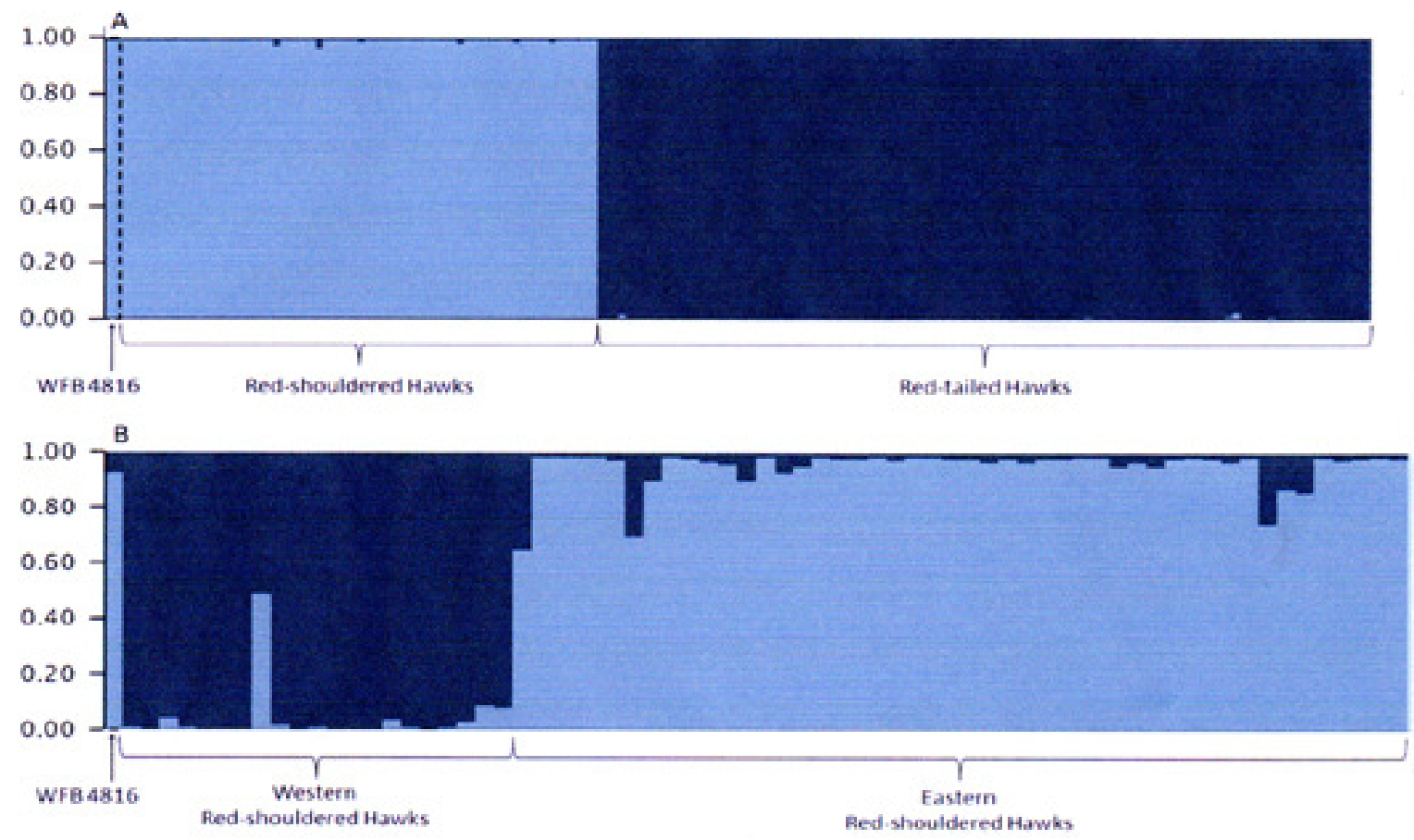

Figure 4. Results of Bayesian clustering analysis of microsatellite genotypes for (A) Red-tailed Hawks, eastern and western Redshouldered Hawks, and WFB 4816 and (B) eastern and western Red-shouldered Hawks and WFB 4816. Figure 4A compares the proportion of ancestry for each individual for $\mathrm{K}=2$ with one population composed of Red-shouldered Hawks (indicated in green) and on population of Red-tailed Hawks (indicated in red). Figure 4B compares the proportion of ancestry for each individual for $\mathrm{K}=2 \mathrm{with}$ one population composed of eastern Red-shouldered Hawks (indicated in green) and one population composed of western Redshouldered Hawks (indicated in red); note that one of the Red-shouldered Hawks sampled in California appears to have mixed eastern and western ancestry. WFB 4816 is at the left of each figure and outlined in a dashed line. In figure 4A WFB 4816 shows a high proportion of Red-shouldered Hawk ancestry and in Figure 4B WFB 4816 ii further indicated as having primarily eastern Redshouldered Hawk ancestry. 
Table 1. Comparison of plumage characters of the putative hybrid specimen with specimens of adult eastern and western Redshouldered Hawks and western Red-tailed Hawks.

\begin{tabular}{|c|c|c|c|c|}
\hline Character & WFB 4816 & Adult East \& West RS's & Adult West RT's & Figure no. \\
\hline Malar \& throat & Uniformly dark & $\begin{array}{l}\text { Darker malars; paler throat, often } \\
\text { with dark streaks }\end{array}$ & Dark or dark with pale streaks & 1 \\
\hline Belly barring & $\begin{array}{l}\text { Dark brown, with short } \\
\text { dark streaks }\end{array}$ & Rufous & $\begin{array}{l}\text { Dark brown with short dark } \\
\text { streaks }\end{array}$ & 1 \\
\hline Uppersides of remiges & $\begin{array}{l}\text { Gray barring, no white } \\
\text { on primaries }\end{array}$ & $\begin{array}{l}\text { Gray barring with white spots } \\
\text { across primaries }\end{array}$ & $\begin{array}{l}\text { Dark brown. No white on } \\
\text { primaries }\end{array}$ & 3 \\
\hline Remige tips & Narrow gray tips & Wide white tips & Dark tips & 3 \\
\hline $\begin{array}{l}\text { Lesser upper wing } \\
\text { coverts }\end{array}$ & $\begin{array}{l}\text { Dark brown with no } \\
\text { rufous }\end{array}$ & Show rufous 'shoulders' & Dark brown & 3 \\
\hline Upper tail coverts & $\begin{array}{l}\text { Dark brown with rufous } \\
\text { and white barring }\end{array}$ & $\begin{array}{l}\text { Dark brown with white barring } \\
\text { only }\end{array}$ & Rufous with dark brown barring & 3 \\
\hline No. of tail bands & $6($ or 7$)$ & 4 or fewer (five had 5 bands) & No pale bands & 2 \\
\hline Tail band color & White with rufous tint & White only, no rufous & No pale bands & 2 \\
\hline
\end{tabular}


411 Appendix 1. Morphometric data used in the PCA. Museum acronyms in specimen identifiers include AMNH (American Museum of 412 Natural History), MSB (Museum of Southwestern Biology of the University of New Mexico), WFVZ (Western Foundation of 413 Vertebrate Zoology), and WFB (Museum of Wildlife and Fish Biology of the University of California-Davis).

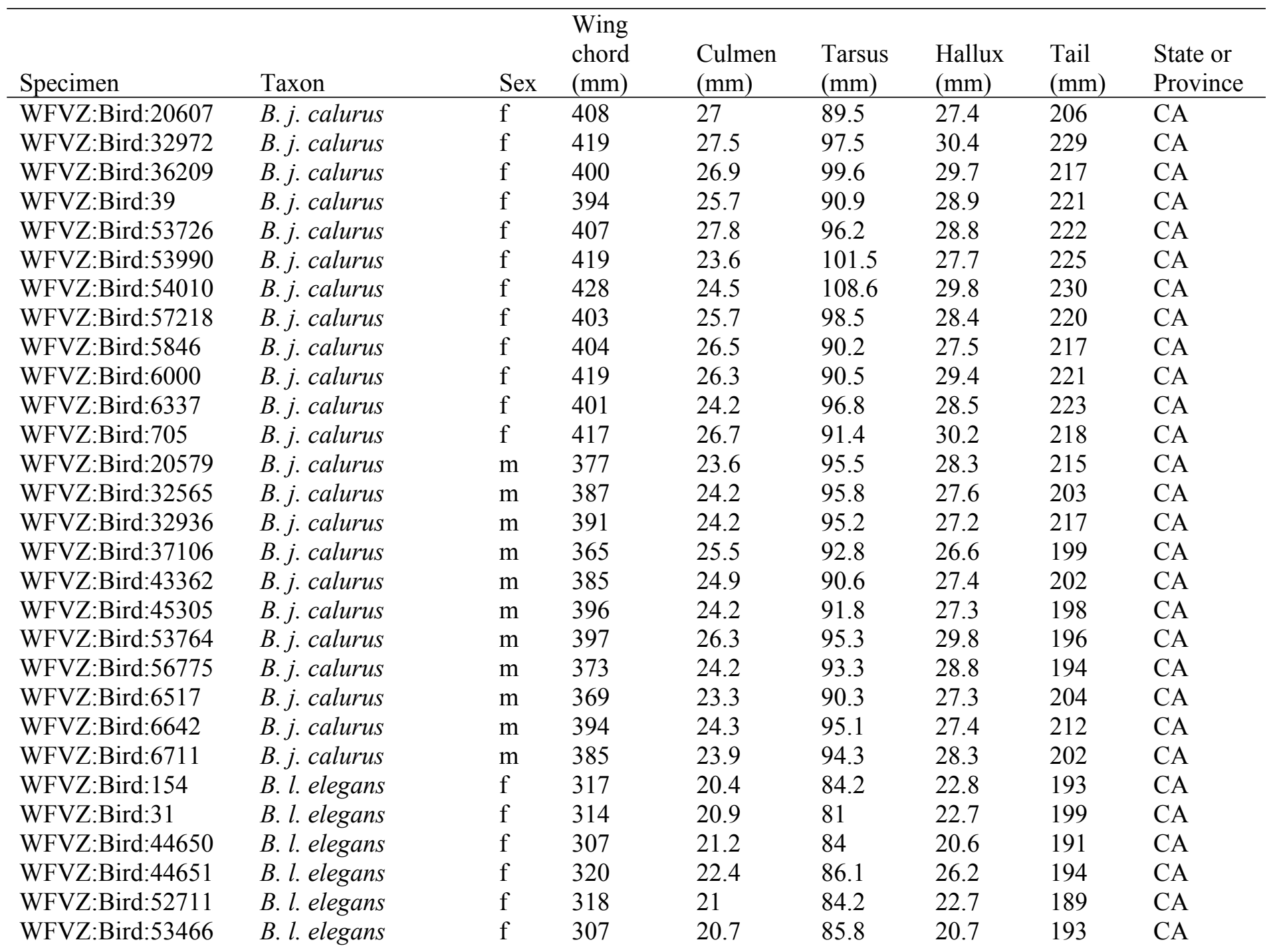




\begin{tabular}{|c|c|c|c|c|c|c|c|}
\hline WFVZ:Bird:53525 & B. l. elegans & $\mathrm{f}$ & 296 & 21.7 & 84.3 & 22.3 & 190 \\
\hline WFVZ:Bird:53751 & B. l. elegans & $\mathrm{f}$ & 289 & 20.1 & 77.5 & 20.5 & 182 \\
\hline WFVZ:Bird:53752 & B. l. elegans & $\mathrm{f}$ & 310 & 20.7 & 81.6 & 22.6 & 192 \\
\hline WFVZ:Bird:54013 & B. l. elegans & $\mathrm{f}$ & 321 & 21.3 & 85.4 & 21.7 & 209 \\
\hline WFVZ:Bird:56778 & B. l. elegans & $\mathrm{f}$ & 300 & 22.2 & 86.8 & 22.5 & 182 \\
\hline WFVZ:Bird:56964 & B. l. elegans & $\mathrm{f}$ & 311 & 20 & 79 & 21.4 & 192 \\
\hline WFVZ:Bird:5985 & B. l. elegans & $\mathrm{f}$ & 312 & 23.2 & 82 & 23 & 202 \\
\hline WFVZ:Bird:6156 & B. l. elegans & $\mathrm{f}$ & 314 & 21.3 & 80.7 & 22.7 & 196 \\
\hline WFVZ:Bird:6274 & B. l. elegans & $\mathrm{f}$ & 310 & 25 & 85.4 & 23 & 203 \\
\hline WFVZ:Bird:710 & B. l. elegans & $\mathrm{f}$ & 301 & 22.6 & 82.3 & 22.2 & 186 \\
\hline MSB:Bird:25344 & B. l. elegans & $\mathrm{m}$ & 293 & 19.56 & 78.53 & 21.17 & 208 \\
\hline WFVZ:Bird:29384 & B. l. elegans & $\mathrm{m}$ & 291 & 20.2 & 78.6 & 22.8 & 180 \\
\hline WFVZ:Bird:32971 & B. l. elegans & $\mathrm{m}$ & 300 & 19.7 & 85 & 18.2 & 173 \\
\hline WFVZ:Bird:3949 & B. l. elegans & $\mathrm{m}$ & 302 & 20.3 & 84.8 & 23.1 & 191 \\
\hline WFVZ:Bird:42145 & B. l. elegans & $\mathrm{m}$ & 283 & 20 & 82.6 & 19.9 & 172 \\
\hline WFVZ:Bird:43374 & B. l. elegans & $\mathrm{m}$ & 297 & 17.8 & 77.2 & 19 & 176 \\
\hline WFVZ:Bird:45273 & B. l. elegans & $\mathrm{m}$ & 278 & 20.8 & 82.3 & 20.2 & 177 \\
\hline WFVZ:Bird:5038 & B. l. elegans & $\mathrm{m}$ & 292 & 20.6 & 78.5 & 18.8 & 180 \\
\hline WFVZ:Bird:52712 & B. l. elegans & $\mathrm{m}$ & 296 & 19.2 & 79.7 & 21.5 & 181 \\
\hline WFVZ:Bird:53484 & B. l. elegans & $\mathrm{m}$ & 292 & 18.2 & 76.4 & 17.8 & 173 \\
\hline WFVZ:Bird:56777 & B. l. elegans & $\mathrm{m}$ & 289 & 20.5 & 80.5 & 20.2 & 187 \\
\hline WFVZ:Bird:5835 & B. l. elegans & $\mathrm{m}$ & 287 & 19 & 76.5 & 19.2 & 173 \\
\hline WFVZ:Bird:5845 & B. l. elegans & $\mathrm{m}$ & 292 & 19.4 & 81.1 & 20.3 & 172 \\
\hline WFVZ:Bird:5921 & B. l. elegans & $\mathrm{m}$ & 286 & 19.5 & 77.3 & 21.3 & 184 \\
\hline WFVZ:Bird:5933 & B. l. elegans & $\mathrm{m}$ & 278 & 20.8 & 83 & 21.4 & 168 \\
\hline WFVZ:Bird:6241 & B. l. elegans & $\mathrm{m}$ & 302 & 18.9 & 81.5 & 20.1 & 181 \\
\hline WFVZ:Bird:6519 & B. l. elegans & $\mathrm{m}$ & 280 & 18.5 & 78.7 & 20.2 & 185 \\
\hline AMNH:Bird:168613 & B. lineatus (eastern) & $\mathrm{f}$ & 352 & 24.42 & 80.85 & 22.92 & 211 \\
\hline AMNH:Bird:352521 & B. lineatus (eastern) & $\mathrm{f}$ & 354 & 24.44 & 79.23 & 23.86 & 204.13 \\
\hline AMNH:Bird:352553 & B. lineatus (eastern) & $\mathrm{f}$ & 355 & 23.95 & 81.13 & 23.18 & 208.8 \\
\hline AMNH:Bird:352559 & B. lineatus (eastern) & $\mathrm{f}$ & 347 & 22.71 & 80.8 & 22.81 & 199.56 \\
\hline AMNH:Bird:470684 & B. lineatus (eastern) & $\mathrm{f}$ & 358 & 22.94 & 80.46 & 21.45 & 208.6 \\
\hline AMNH:Bird:69780 & B. lineatus (eastern) & $\mathrm{f}$ & 359 & 20.24 & 85.4 & 23.9 & 198.45 \\
\hline AMNH:Bird:69781 & B. lineatus (eastern) & $\mathrm{f}$ & 346 & 22.06 & 81.04 & 22.25 & 213 \\
\hline AMNH:Bird:750225 & B. lineatus (eastern) & $\mathrm{f}$ & 355 & 21.31 & 75.5 & 21.6 & 208.8 \\
\hline AMNH:Bird:832602 & B. lineatus (eastern) & $\mathrm{f}$ & 359 & 23.4 & 84.3 & 23.25 & 211 \\
\hline
\end{tabular}




\begin{tabular}{|c|c|c|c|c|c|c|c|c|}
\hline AMNH:Bird:96626 & B. lineatus (eastern) & $\mathrm{f}$ & 328 & 20 & 74.66 & 21.66 & 200.67 & NY \\
\hline MSB:Bird:24325 & B. lineatus (eastern) & $\mathrm{f}$ & 321 & 21.5 & 74.45 & 20.89 & 194 & LA \\
\hline MSB:Bird:24885 & B. lineatus (eastern) & $\mathrm{f}$ & 307 & 22.22 & 77.14 & 21.81 & 185 & FL \\
\hline MSB:Bird:4291 & B. lineatus (eastern) & $\mathrm{f}$ & 352 & 22.55 & 76.81 & 22.78 & 211 & IA \\
\hline WFVZ:Bird:20446 & B. lineatus (eastern) & $\mathrm{f}$ & 340 & 21.5 & 84.9 & 21.7 & 200 & PA \\
\hline WFVZ:Bird:20447 & B. lineatus (eastern) & $\mathrm{f}$ & 350 & 21.1 & 82.5 & 21.8 & 203 & GA \\
\hline WFVZ:Bird:20464 & B. lineatus (eastern) & $\mathrm{f}$ & 335 & 22.2 & 84.6 & 23.1 & 195 & GA \\
\hline WFVZ:Bird:20472 & B. lineatus (eastern) & $\mathrm{f}$ & 325 & 20.7 & 84.7 & 19.5 & 207 & $\mathrm{NJ}$ \\
\hline WFVZ:Bird:20476 & B. lineatus (eastern) & $\mathrm{f}$ & 345 & 21.9 & 84 & 21.5 & 209 & MD \\
\hline WFVZ:Bird:20477 & B. lineatus (eastern) & $\mathrm{f}$ & 341 & 20.1 & 86.8 & 20.7 & 213 & $\mathrm{NJ}$ \\
\hline WFVZ:Bird:20481 & B. lineatus (eastern) & $\mathrm{f}$ & 343 & 20.6 & 84.9 & 22.3 & 205 & PA \\
\hline WFVZ:Bird:20483 & B. lineatus (eastern) & $\mathrm{f}$ & 327 & 19.7 & 81.7 & 21.1 & 204 & PA \\
\hline WFVZ:Bird:20490 & B. lineatus (eastern) & $\mathrm{f}$ & 337 & 21.3 & 84.8 & 19.2 & 181 & FL \\
\hline WFVZ:Bird:47830 & B. lineatus (eastern) & $\mathrm{f}$ & 350 & 22.9 & 81.9 & 22.7 & 214 & $\mathrm{NC}$ \\
\hline WFVZ:Bird:49754 & B. lineatus (eastern) & $f$ & 324 & 20 & 84.2 & 22.2 & 197 & $\mathrm{TX}$ \\
\hline AMNH:Bird:234136 & B. lineatus (eastern) & $\mathrm{m}$ & 316 & 20.22 & 75.81 & 20.43 & 188.47 & $\mathrm{ON}$ \\
\hline AMNH:Bird:352520 & B. lineatus (eastern) & $\mathrm{m}$ & 339 & 20.24 & 80.71 & 20.79 & 200.19 & IA \\
\hline AMNH:Bird:352526 & B. lineatus (eastern) & $\mathrm{m}$ & 346 & 21.14 & 82.17 & 20.11 & 194.75 & MO \\
\hline AMNH:Bird:352531 & B. lineatus (eastern) & $\mathrm{m}$ & 335 & 22.45 & 77.9 & 20.72 & 195.57 & $\mathrm{NJ}$ \\
\hline AMNH:Bird:352535 & B. lineatus (eastern) & $\mathrm{m}$ & 333 & 22.82 & 79.21 & 21.27 & 184.32 & NY \\
\hline AMNH:Bird:470683 & B. lineatus (eastern) & $\mathrm{m}$ & 330 & 19.69 & 73.18 & 20.41 & 202.38 & $\mathrm{ON}$ \\
\hline AMNH:Bird:832603 & B. lineatus (eastern) & $\mathrm{m}$ & 324 & 21.74 & 79.52 & 21.11 & 193.77 & MA \\
\hline AMNH:Bird:832604 & B. lineatus (eastern) & $\mathrm{m}$ & 337 & 21.71 & 80.14 & 20.91 & 200.7 & RI \\
\hline AMNH:Bird:836423 & B. lineatus (eastern) & $\mathrm{m}$ & 341 & 19.91 & 74 & 20.38 & 195.24 & RI \\
\hline AMNH:Bird:98112 & B. lineatus (eastern) & $\mathrm{m}$ & 334 & 21.11 & 77.29 & 21.67 & 197 & MA \\
\hline MSB:Bird:21684 & B. lineatus (eastern) & $\mathrm{m}$ & 306 & 19.57 & 73.52 & 21.63 & 207 & $\mathrm{TX}$ \\
\hline WFVZ:Bird:20461 & B. lineatus (eastern) & $\mathrm{m}$ & 321 & 19.5 & 83.1 & 22.2 & 194 & PA \\
\hline WFVZ:Bird:20465 & B. lineatus (eastern) & $\mathrm{m}$ & 329 & 19.1 & 79.2 & 21 & 183 & $\mathrm{NJ}$ \\
\hline WFVZ:Bird:20470 & B. lineatus (eastern) & $\mathrm{m}$ & 310 & 20 & 79.8 & 19.8 & 185 & GA \\
\hline WFVZ:Bird:20471 & B. lineatus (eastern) & $\mathrm{m}$ & 319 & 20.8 & 77 & 18.4 & 189 & GA \\
\hline WFVZ:Bird:20472 & B. lineatus (eastern) & $\mathrm{m}$ & 308 & 18.8 & 78.5 & 20.3 & 184 & PA \\
\hline WFVZ:Bird:20473 & B. lineatus (eastern) & $\mathrm{m}$ & 323 & 21.2 & 84.8 & 19.9 & 195 & GA \\
\hline WFVZ:Bird:20474 & B. lineatus (eastern) & $\mathrm{m}$ & 313 & 19.5 & 79 & 21.9 & 186 & GA \\
\hline WFVZ:Bird:20497 & B. lineatus (eastern) & $\mathrm{m}$ & 311 & 20 & 75 & 20 & 192 & GA \\
\hline WFVZ:Bird:20499 & B. lineatus (eastern) & $\mathrm{m}$ & 315 & 19.7 & 75.9 & 19.7 & 185 & GA \\
\hline WFVZ:Bird:48010 & B. lineatus (eastern) & $\mathrm{m}$ & 302 & 18.9 & 78.3 & 18.4 & 186 & GA \\
\hline
\end{tabular}




\begin{tabular}{lllllllll} 
WFVZ:Bird:50191 & B. lineatus (eastern) & $\mathrm{m}$ & 318 & 20.2 & 76.7 & 21.7 & 197 & TX \\
WFB:Bird:4816 & Putative hybrid & $\mathrm{n} / \mathrm{a}$ & 350 & 23.9 & 83.2 & 25.12 & 212 & CA \\
\hline
\end{tabular}


Appendix 2. Measurements of hallux chord from 98 adult female $B$. l. lineatus specimens $(\overline{\mathrm{x}}=22.1, \mathrm{SD}=1.0$, range 19.2-23.9). Museum acronyms in specimen identifiers include AMNH (American Museum of Natural History), BMUW (University of Washington Burke Museum), MSB (Museum of Southwestern Biology of the University of New Mexico), MVZ (Museum of Vertebrate Zoology of the University of California-Berkeley), USNM (Smithsonian Institution), WFVZ (Western Foundation of Vertebrate Zoology), and WFB (Museum of Wildlife and Fish Biology of the University of California-Davis).

\begin{tabular}{lcc}
\hline Specimen & Hallux $(\mathrm{mm})$ & State/Province/Country \\
\hline USNM:Bird:41683 & 22 & DC \\
USNM:Bird:1278 & 22.9 & PA \\
USNM:Bird:372246 & 20.7 & LA \\
USNM:Bird:74360 & 21.8 & Mexico \\
USNM:Bird:84511 & 21.4 & IL \\
USNM:Bird:84512 & 21.3 & IL \\
USNM:Bird:85456 & 23.9 & IL \\
USNM:Bird:101620 & 23.3 & PA \\
USNM:Bird:121489 & 23.2 & PA \\
USNM:Bird:124977 & 22.6 & MD \\
USNM:Bird:141121 & 22.2 & MD \\
USNM:Bird:160852 & 23.7 & GA \\
USNM:Bird:176027 & 22 & MD \\
USNM:Bird:204909 & 23.9 & MD \\
USNM:Bird:231534 & 22.2 & IL \\
USNM:Bird:257191 & 22.9 & MR \\
USNM:Bird:271233 & 21.3 & NJ \\
USNM:Bird:271235 & 22.7 & NJ \\
USNM:Bird:272298 & 22.7 & MD \\
USNM:Bird:293611 & 21.9 & MD \\
USNM:Bird:293613 & 20.9 & NC \\
USNM:Bird:302987 & 23.6 & MD \\
USNM:Bird:305541 & 21.2 & MD \\
USNM:Bird:307940 & 22.8 & NJ \\
USNM:Bird:309401 & 21.6 &
\end{tabular}




$\begin{array}{llc}\text { USNM:Bird:311751 } & 20.6 & \text { NJ } \\ \text { USNM:Bird:313564 } & 20.6 & \text { PA } \\ \text { USNM:Bird:333275 } & 20.9 & \text { VA } \\ \text { USNM:Bird:337332 } & 23.4 & \text { KY } \\ \text { USNM:Bird:350854 } & 22.5 & \text { TN } \\ \text { USNM:Bird:350855 } & 22.1 & \text { TN } \\ \text { USNM:Bird:358210 } & 22.6 & \text { TN } \\ \text { USNM:Bird:361787 } & 21.8 & \text { NC } \\ \text { USNM:Bird:361788 } & 21.7 & \text { SC } \\ \text { USNM:Bird:361790 } & 22.2 & \text { SC } \\ \text { USNM:Bird:363767 } & 20.4 & \text { SC } \\ \text { USNM:Bird:378649 } & 23.6 & \text { GA } \\ \text { USNM:Bird:378763 } & 21.6 & \text { MD } \\ \text { USNM:Bird:414277 } & 20.6 & \text { NY } \\ \text { USNM:Bird:419685 } & 22.5 & \text { NY } \\ \text { USNM:Bird:479274 } & 21.7 & \text { OK } \\ \text { USNM:Bird:524102 } & 21.7 & \text { IA } \\ \text { USNM:Bird:524104 } & 23.4 & \text { MD } \\ \text { USNM:Bird:524105 } & 20.5 & \text { MD } \\ \text { USNM:Bird:524107 } & 22.5 & \text { MD } \\ \text { USNM:Bird:524108 } & 22.1 & \text { MD } \\ \text { USNM:Bird:524111 } & 21.3 & \text { MD } \\ \text { USNM:Bird:532317 } & 22.9 & \text { MD } \\ \text { USNM:Bird:565400 } & 21.9 & \text { IN } \\ \text { USNM:Bird:567311 } & 21.8 & \text { IN } \\ \text { USNM:Bird:588436 } & 22.2 & \text { PA } \\ \text { USNM:Bird:599472 } & 22.2 & \text { MD } \\ \text { USNM:Bird:602033 } & 22.9 & \text { VA } \\ \text { BMUW:Bird:79527 } & 20.1 & \text { NA } \\ \text { BMUW:Bird:76102 } & 23.2 & \end{array}$




$\begin{array}{lcc}\text { FMNH:Bird:67098 } & 21.7 & \text { CT } \\ \text { FMNH:Bird:324665 } & 21.8 & \text { IL } \\ \text { FMNH:Bird:300779 } & 21.9 & \text { IL } \\ \text { FMNH:Bird:435708 } & 22.2 & \text { NJ } \\ \text { FMNH:Bird:16203 } & 22.3 & \text { IL } \\ \text { FMNH:Bird:130422 } & 22.4 & \text { CT } \\ \text { FMNH:Bird:74686 } & 22.5 & \text { CT } \\ \text { FMNH:Bird:88367 } & 23 & \text { AR } \\ \text { FMNH:Bird:20914 } & 23.5 & \text { IL } \\ \text { MVZ:Bird:99787 } & 20.7 & \text { CT } \\ \text { MVZ:Bird:144675 } & 20.8 & \text { IL } \\ \text { MVZ:Bird:58416 } & 21.5 & \text { SC } \\ \text { MVZ:Bird:127228 } & 22.2 & \text { KS } \\ \text { MVZ:Bird:127231 } & 23.4 & \text { MA } \\ \text { MVZ:Bird:94366 } & 23.7 & \text { MA } \\ \text { AMNH:Bird:168613 } & 22.9 & \text { NY } \\ \text { AMNH:Bird:352251 } & 23.9 & \text { IA } \\ \text { AMNH:Bird:352553 } & 23.2 & \text { NH } \\ \text { AMNH:Bird:352559 } & 22.8 & \text { ON } \\ \text { AMNH:Bird:470684 } & 21.5 & \text { ON } \\ \text { AMNH:Bird:69780 } & 23.9 & \text { NJ } \\ \text { AMNH:Bird:69781 } & 22.3 & \text { MD } \\ \text { AMNH:Bird:750225 } & 21.6 & \text { CT } \\ \text { AMNH:Bird:832602 } & 23.3 & \text { RI } \\ \text { AMNH:Bird:96626 } & 21.7 & \text { NY } \\ \text { MSB:Bird:24325 } & 20.9 & \text { LA } \\ \text { MSB:Bird:24885 } & 21.8 & \text { FL } \\ \text { MSB:Bird:4291 } & 22.8 & \text { LA } \\ \text { WFVZ:Bird:20446 } & 21.7 & \text { PA } \\ \text { WFVZ:Bird:20447 } & 21.8 & \text { NJ } \\ \text { WFVZ:Bird:20464 } & 23.1 & \\ \text { WFVZ:Bird:20472 } & 19.5 & 21.5 \\ \text { WFVZ:Bird:20476 } & & \text { MD }\end{array}$




\begin{tabular}{lll} 
WFVZ:Bird:20477 & 20.7 & NJ \\
WFVZ:Bird:20481 & 22.3 & PA \\
WFVZ:Bird:20483 & 21.1 & PA \\
WFVZ:Bird:20490 & 19.2 & FL \\
WFVZ:Bird:47830 & 22.7 & NC \\
WFVZ:Bird:47954 & 22.2 & TX \\
\hline
\end{tabular}

421

422

423

424 


\section{PeerJ}

425 Appendix 3. Raw Microsat data. (Excel file)

426 